\title{
OPTIMAL PARAMETERS FOR In Vitro DEVELOPMENT OF THE HYDROCARBONOCLASTIC MICROORGANISM Proteus sp.
}

\author{
M.A. Hernández-Rivera ${ }^{1}$, M.E. Ojeda-Morales ${ }^{1}$, J.G. Martínez-Vázquez ${ }^{2} *$, V.M. \\ Villegas-Cornelio ${ }^{3}$ and Y. Córdova-Bautista ${ }^{1}$.
}

\begin{abstract}
${ }^{1}$ División Académica de Ingeniería y Arquitectura, Universidad Juárez Autónoma de Tabasco, Km. 1 Carretera Cunduacán-Jalpa, Colonia Esmeralda, Cunduacán, Tabasco, México, CP: 86040. ${ }^{2}$ Centro de Apoyo Pedagógico, Universidad de Atacama, Av. Copayapu 485, Copiapó, Región de Atacama, Chile, CP: $1530000 .{ }^{3}$ Dpto. de Ciencias Químico-Biológicas, Universidad Popular de la Chontalpa, Km. 2 Carretera Cárdenas-Huimanguillo, Cárdenas, Tabasco, México. CP: 86500. *Corresponding author: gabrielm81@hotmail.com
\end{abstract}

\begin{abstract}
In México, there are extensive areas polluted by oil spills. Currently, bioremediation technologies have been developed, using microorganisms to clean up oil sites. In this study, we evaluated the development of a hydrocarbonoclastic bacterial strain, using a completely randomized $3 \times 3 \times 4$ factor arrangement: three temperatures, three $\mathrm{pH}$, and four nutrients. We collected samples of soil contaminated with $3.45 \times 10^{5} \mathrm{mg} \mathrm{kg}^{-1}$ $(345,000 \mathrm{ppm})$ Total Petroleum Hydrocarbons (TPH), located at the Ejido José N. Rovirosa, Huimanguillo, Tabasco, México. The samples were grown in a culture medium Nutrient Agar (NA), obtaining a bacterial strain, which was characterized and classified as Proteus sp. The strain was grown in a combined carbon culture medium and then in a liquid mineral medium with crude oil as sole carbon source. Analysis of variance and mean test were performed, using the SPSS-11.0 statistical software. The microorganisms showed the highest population growth in the treatment

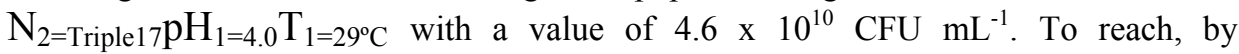
bioaugmentation, the same development of Proteus $\mathrm{sp}$ in a conditioned soil would allow us to implement a potential bioremediation strategy for solving the problem of soils contaminated with hydrocarbons in the state of Tabasco in particular, and in Mexico in general.
\end{abstract}

Keywords: hydrocarbon degrading cells, optimal growth, Proteus sp, hydrocarbonoclastic.

\section{INTRODUCTION}

The exploitation of natural resources in the state of Tabasco has highly contributed to the Mexican economy. Being this contribution a $5.7 \%$ of the Gross Domestic Product (GDP) in industrial related activities. Oil and gas extraction, mining and electricity generation are among the most important of these activities (INEGI, 2009). Just the extraction of crude oil, from wells of this state located in the Mexican southeast, has contributed with a $3.7 \%$ of the total national GDP (Arias, 210). A total of 2.6 million daily barrels of crude oil were extracted in México in 2009; $77.5 \%$ obtained from wells in the waters of 
Mexican Gulf (Cruz-Serrano, 2010), and $17.3 \%$ from wells located in Tabasco (Hernández, 2009), which has a total extension of $24,751 \mathrm{~km}^{2}(2,475,100 \mathrm{ha})$. As a result of the oil industry activities in Tabasco, Petróleos Mexicanos (PEMEX), with the support of the Instituto Mexicano del Petroleo (IMP), identified $3.0 \mathrm{~km}^{2}$ ( $300 \mathrm{ha}, 1 \mathrm{ha}=10000 \mathrm{~m}^{2}$ ) polluted by the spillage of crude oil in the state and 138 reservoirs polluted by oil wastes (LajousVargas, 1997). Furthermore, the Comisión Interinstitucional para el Medio Ambiente y el Desarrollo Social (CIMADES, 1997) reported the existence of 6480 ha affected, located in marshes and flood zones. The reports are not conclusive neither regarding the zones recovered from that environmental degradation (Cruz-Serrano, 2009; RamosMora, 2010), nor the existence of new polluted zones. It only states, in general terms, that according to PEMEX, 1140 ha were polluted nationwide during 2009 (Ramos-Mora, 2010).

There have been many consequences derived from polluting the ecosystems of this tropical region. Even though pollution can hardly be stopped, it can be controlled by bringing it to tolerable levels, according to the current environmental legislation. Drilling and extraction processes have dramatically increased, as well as, oil products storage and transportation, and with them the risk of accidents such as spillages and leaks. Furthermore, the oil industry produces a great amount of wastes with hydrocarbon content which is necessary to temporarily keep in safe sites like storage tanks or special containers (Eweiss et al., 1999) until they are re-used or treated. Accidents in the oil industry like pipe ruptures and shipwrecks cause oil spills on marine and terrestrial ecosystems thus affecting their physical and chemical properties as well as their biological components. These accidents prevent the affected natural resources from being rationally exploited, because the productive processes are altered or the species habitat and the natural landscape aesthetics are directly modified (Levin and Gealt, 1997; Eweis et al., 1999; Zavala et al., 2003). As a matter of fact, hydrocarbons spills on these ecosystems have motivated bioremediation studies for these sites.

Active Bioremediation is a technology that uses the metabolic potential of microorganisms to clean up polluted environments. It is characterized for taking place in open environments (non sterile) with a wide diversity of organisms (Watanabe, 2001). It is a generalized technique to clean up petroleum hydrocarbons. Due to its simple application it can be used on large areas, it is cost effective, and removes the contaminant completely (Frankenberger, 1992). Strategies used by bioremediation on polluted soils include biostimulation of indigenous microorganisms by adding nutrients, water and oxygen to the soil, or bioaugmentation that refers to the inoculation of a strain or enriched microbial consortium (Walter, 1997; Atlas and Unterman, 1999; Barathi and Vasudevan, 2001; Seklemova et al., 2001). Indigenous microbes do not always have the capability to degrade a particular contaminant or sometimes their quantity is not enough to perform the remediation process. Bioaugmentation is a form to provide specific microbes in sufficient quantities to complete biodegradation (Walter, 1997). There exist great quantities of heterotrophic organisms capable of using petroleum hydrocarbons as a source of carbon and energy. They use them to produce carbon dioxide, water, biomass and other less toxic products (Davies, 1997). Microorganisms tolerant to this polluted environment oxidize the hydrocarbons by the action of monooxygenases and dioxygenases, 
converting them into other more soluble and unstable components (Lee and Levy, 1989; Atlas et al., 1991; AdamsSchroeder et al., 2002). Saturated and aromatic components with one to five benzene rings are used by the microorganisms as energetic sources (Sugiura et al., 1997).

The metabolic potential of microorganisms to degrade oil finds favorable conditions of temperature, nutrients, $\mathrm{pH}$, Oxygen, and humidity in tropical soils (Rivera-Cruz et al., 2002). That is why it is necessary to determine, in vitro, the effect of nutrients and diverse physical and chemical parameters that favor the growth of degrading hydrocarbon microorganisms in these kinds of soils, in order to select those which can help recover oil-polluted soils in the state of Tabasco, México.

\section{MATERIALS AND METHODS}

\section{Stage 1. Evaluation, characterization and adaptation of hydrocarbonoclastic bacteria.}

The experiment was performed in two stages. The first had three phases that involved, in general terms: evaluation, characterization, isolation, purification and preservation of hydrocarbonoclastic microorganisms. Samples of a polluted site were collected. This site is being affected by the installation of an oil field located at the Ejido Jose Narciso Rovirosa, La Venta, and belongs to the municipality of Huimanguillo, Tabasco in México. The annual average temperature is $32{ }^{\circ} \mathrm{C}$ and the altitude is 20 masl (INEGI, 2001).

Simple soil samples for a total of 5000 $\mathrm{m}^{2}$ ( $\left.0.5 \mathrm{ha}\right)$ were collected by applying the methodology indicated by the Norma Oficial Mexicana 021 (NOM-021-
RECNAT-2000, 2002). Then, the samples were placed in glass bottles that had been previously labeled with the sampling date. Once in the bottles, they were kept in ice coolers and sent to the laboratory to be stored under refrigeration at $4.0^{\circ} \mathrm{C}$. Then, the oil-derived hydrocarbons were extracted by using the Extraction Method (EPA-3540C, 1996; EPA-9071B, 1998) in their heavy fraction and then quantified by gravimetry (EPA-1664A, 1999). The different bacterial strains obtained by the sampling were evaluated in phase I.

\section{Phase I}

The evaluation, characterization, isolation, purification and preservation of total bacteria were done in relation to their growth and reproduction in the culture medium agar nutrient for total bacteria (AN). The agar nutrient was prepared by dissolving $15.0 \mathrm{~g}$ of agar, 3.0 $\mathrm{g}$ of beef extract, $5.0 \mathrm{~g}$ of Peptone in $1 \mathrm{~L}$ of distilled water and was sterilized as indicated by Ramirez (2000). After that, the culture medium AN was poured into a petri dish, close to a flame. The selection test was based on the evaluation of the reproduction that the soil microorganisms developed on the AN. A dilution was prepared with $10.0 \mathrm{~g}$ of soil in $90 \mathrm{~mL}$ distilled sterile water. From this dilution two serial dilutions were prepared: $1 \mathrm{~mL}$ of the former dilution was suspended in 9 $\mathrm{mL}$ distilled sterile water $\left(10^{-1}\right)$, and from this, an additional dilution was formed $\left(10^{-2}\right)$. Then, $0.1 \mathrm{~mL}$ of the dilution $10^{-1}$ was poured into each of the 6 petri dishes with AN, and spread over with a Drigalski spatula for an even distribution. The same action was done with dilution $10^{-2}$ and they were incubated at $28^{\circ} \mathrm{C}$ during $48 \mathrm{~h}$. The microorganisms were counted using the viable cell counting method (Madigan et al., 2003). The three strains found, named B1, B2 and B3 passed to the following phase. 


\section{Phase II}

Adaptation in a combined carbon culture medium for degrading bacteria of total petroleum hydrocarbons (CCM). The glass material was sterilized with dry heat in a period of $4 \mathrm{~h}$ at $180^{\circ} \mathrm{C}$ (Pelczar et al., 1998). The CCM, the Istmo crude oil type with API index = 33.74 (PEMEX, 1998), in its heavy fraction (with molecules higher to $\mathrm{C} 18$ ), and the filter paper (squares of $1.5 \mathrm{~cm}$ for each side) were sterilized with humid heat during $20 \mathrm{~min}$ in autoclave at $121^{\circ} \mathrm{C}$ and $127.486 \mathrm{kPa}$ $\left(1.3 \mathrm{kgf} \mathrm{cm}^{-2}\right)$. The CCM was prepared according to the methodology of Rennie (1981) modified by Ferrera- Cerrato (River-Cruz et al., 2002). Petri dishes were prepared with the CCM, where carbon source was replaced by a filter paper square of $1.5 \times 1.5 \mathrm{~cm}$ impregnated with Istmo crude oil in axenic conditions. The paper was placed on the CCM in the Petri dish. Meanwhile, with the help of a platinum handle the micelles of B1, B2 and B3 microorganisms, resulting from culture medium AN in the first phase, were touched and striated over the clean CCM medium. After that, the Petri dish lid was placed. The sowing was performed in triplicate in the solid medium for each of the three bacteria colonies. Finally, they were incubated at $29^{\circ} \mathrm{C}$ for a period of $6 \mathrm{~d}$. The strain with higher reproduction passed to Phase III.

\section{Phase III}

Bacteria adaptation in liquid culture medium of combined carbon modified for degrading bacteria of total petroleum hydrocarbons (MLC). This test consisted on placing the strain obtained from Phase II in the MLC medium having the Istmo crude oil as its only carbon source. 500 $\mathrm{mL}$ of MLC were prepared according to Rennie (1981) modified by FerreraCerrato (Rivera-Cruz et al., 2002). 100
$\mathrm{mL}$ of MLC were added in triplicate in a $250 \mathrm{~mL}$ Erlenmeyer flask. On the other hand, the strain B1 from the medium CCM was touched with a platinum handle (Phase II) and immersed in $5 \mathrm{~mL}$ of bidistilled sterile water. After that, $1 \mathrm{~mL}$ of the bacterial dilution and $1 \mathrm{~mL}$ of crude oil were added to each of the $100 \mathrm{~mL}$ of MLC (Rivera-Cruz, 2001). They were shaken for $30 \mathrm{~min}$ and rested during 5 min. Immediately after, the three flasks were sampled $(\mathrm{t}=0 \mathrm{~h})$, sowing in triplicate $1 \mathrm{~mL}$ of MLC/bacteria/petroleum in petri dishes with AN. The bacteria samples in $\mathrm{AN}$ were incubated at $29^{\circ} \mathrm{C}$ during $24 \mathrm{~h}$ and then the Colony Forming Units (CFU) were quantified by the viable cell counting method (Madigan, 2003). The flaks with $\mathrm{MLC} /$ bacteria/Petroleum were kept at $29^{\circ} \mathrm{C}$ during $7 \mathrm{~d}$, adding $1 \mathrm{~mL}$ of Istmo oil every $24 \mathrm{~h}$. Similar samples were performed every $24 \mathrm{~h}$ during the period of time that the experiment lasted. To preliminary gender differentiation, the bacterial strain B1 was inoculated in Trypticase Soy Agar, Blood Agar and Eosine Methylene Blue Agar, and from this last culture medium, biochemical tests were performed to identify, at a gender level, the bacterial strain: microscopic morphology, catalase, oxidase, $\mathrm{H}_{2} \mathrm{~S}$ production, motility, growth in $\mathrm{KCN}$, carbohydrates fermentation tests, IMVIC reactions, nitrate reduction, lipase, urease, catalase, use of acetate and OrthoNitrophenyl Galactopyranoside (Holt et al., 1994). The microorganism classified as Proteus sp was preserved in $\mathrm{AN}$ in an inclined tube at $4.0^{\circ} \mathrm{C}$ to determine optimal parameters of its development in Stage II.

\section{Stage II. Development of an experimental design to determine optimal growth parameters.}

The second stage was performed in two phases. In the first phase an in vitro 
bioassay was applied, based on an experimental design, where the chosen bacterium growth was tested in four nutrient media, with variations in $\mathrm{pH}$ and temperature. In the second phase, a bacterial biomass production test was performed in a bioreactor (Kettler jar), using the parameters that stimulated the microorganism optimal development.

\section{Phase I}

Development of an experimental design to determine optimal growth parameters. An in vitro bioassay was carried out, based on a completely randomized experimental design with a $3 \times 3 \times 4$ factorial arrangement: Three temperature

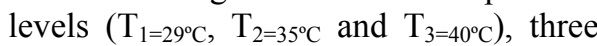
$\mathrm{pH}$ levels $\left(\mathrm{pH}_{1=4.0}, \mathrm{pH}_{2=6.0}\right.$ and $\left.\mathrm{pH}_{3=8.0}\right)$ and four nutrient levels $\left(\mathrm{N}_{1=\text { Urea }}, \mathrm{N}_{2=\text { Triple } 17}\right.$,

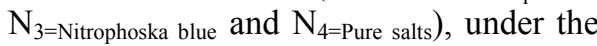
statistical model:

$\mathrm{Y}_{\mathrm{ijk}}=\mu+\mathrm{T}_{\mathrm{i}}+\mathrm{N}_{\mathrm{j}}+\mathrm{pH}_{\mathrm{k}}+\mathrm{T}_{\mathrm{i}} \mathrm{N}_{\mathrm{j}}+\mathrm{T}_{\mathrm{i}} \mathrm{pH}_{\mathrm{k}}+\mathrm{N}_{\mathrm{i}} \mathrm{pH}_{\mathrm{j}}+\xi(\mathrm{ijk})$

To perform the experiment and to optimize the $35^{\circ} \mathrm{C}$ and $40^{\circ} \mathrm{C}$ temperatures, two glass trays were used, each one connected to an electrical heater. A water re-circulating pump was used to keep the water at a constant temperature. $250 \mathrm{~mL}$ Erlenmeyer flasks were used, distributed in three series of twelve treatments, to determine the nutrient parameters and $\mathrm{pH}$. The flasks were connected to an air compressor. Membrane filters and control valves were employed so that sterile air could be supplied.

\section{Preparation of immersed culture media}

The nutrient media were: $\mathrm{N}_{1}=$ Urea (Abbot), $\mathrm{N}_{2}=$ Triple 17 (NPK, RLM), $\mathrm{N}_{3}=$ Nitrophoska blue 12-12-17-6 (NPKS, Compo) and $\mathrm{N}_{4}=$ Pure salts $\left(\mathrm{Na}_{2} \mathrm{HPO}_{4}\right.$, $\mathrm{KH}_{2} \mathrm{PO}_{4}, \mathrm{NH}_{4} \mathrm{CI}, \mathrm{MgSO}_{4} \cdot 7 \mathrm{H}_{2} \mathrm{O}$ ) (Kästner et al., 1994), prepared with equal proportions of $\mathrm{C}$, and the same Peptone quantity (Merck) added to each medium. The nutrient fertilizers had proportional relations of the following NPK elements: proportion between Pure salts-Triple 17, $\mathrm{N}$ (approx. 1:1), P (approx.4:1), K (approx 2:1), respectively; proportion between Triple 17-Nitrophoska blue, K (1:1), P (2.8:1) and $\mathrm{N}$ (2.8:1); proportion between Urea-Pure salts, N (3.4:1). Also, the load in mass was the same for the three organic fertilizers. The media were prepared as follows: for each of the four media three Erlenmeyer flasks were prepared with $500 \mathrm{~mL}$ of distilled water (Química Mercurio) and $1.0 \mathrm{~g}$ of beef Peptone as carbon source. The first medium contained $0.50 \mathrm{~g}$ of Urea, the second $0.50 \mathrm{~g}$ of triple 17 , the third $0.50 \mathrm{~g}$ of Nitrophoska blue and the fourth 1.065 $\mathrm{g}$ of $\mathrm{Na}_{2} \mathrm{HPO}_{4}$ (Fermont), $0.650 \mathrm{~g}$ of $\mathrm{KH}_{2} \mathrm{PO}_{4}$ (Fermont), $0.250 \mathrm{~g}$ of $\mathrm{NH}_{4} \mathrm{Cl}$ (Golden Bell), $0.100 \mathrm{~g}$ of $\mathrm{MgSO}_{4} \cdot 7 \mathrm{H}_{2} \mathrm{O}$ (J.T. Baker), making a total of 12 flasks. Subsequently, each nutrient media had the $\mathrm{pH}$ adjusted at 4.0, 6.0 and 8.0 respectively by using $0.1 \mathrm{M}$ dilutions of $\mathrm{H}_{2} \mathrm{SO}_{4}$ (J.T. Baker) and $\mathrm{NaOH}$ (J.T. Baker). To test the nutrient media at the $\mathrm{T}_{1=29^{\circ} \mathrm{C}}, \mathrm{T}_{2=35^{\circ} \mathrm{C}}$ and $\mathrm{T}_{3=40^{\circ} \mathrm{C}}$ temperatures, $170 \mathrm{~mL}$ of each nutrient medium with its adjusted $\mathrm{pH}$ were measured and placed in a $250 \mathrm{~mL}$ flask, thus obtaining 36 experimental units (e.u.), according to the experimental design. The u.e. were sterilized during $20 \mathrm{~min}$ at $121^{\circ} \mathrm{C}$ and $103.421 \mathrm{kPa}\left(15 \mathrm{lb}_{\mathrm{f}} \mathrm{plg}^{-2}\right)$. Afterward, these e.u. were inoculated with Proteus sp.

\section{Preparing inoculation}

The bacterial strain to inoculate in the 36 e.u. was obtained from the $\mathrm{MLC} /$ bacteria/petroleum colonies, preserved in $\mathrm{AN}$, at $4.0^{\circ} \mathrm{C}$ in Phase III of Stage 1. A sterile handle was used to extract the bacterium from the 
preservation medium and then it was sown in a petri dish with $\mathrm{AN}$, then it was incubated at $29^{\circ} \mathrm{C}$ for a period of $36 \mathrm{~h}$. After that, bacterial biomass contained in the AN was taken with a platinum handle and placed in $5 \mathrm{~mL}$ of distilled sterile water, it was shaken and then poured into an Erlenmeyer flask with 100 $\mathrm{mL}$ of water under axenic conditions. 1.5 $\mathrm{mL}$ of this inoculating medium was then injected, with a sterile syringe, in each of the 36 e. u. under axenic conditions, they were shaken to homogenize, and the initial amount of the inoculant was determined as $\mathrm{CFU}$ of Proteus sp $(\mathrm{t}=0 \mathrm{~h})$. The Proteus sp growth test in the e.u. was carried out every $24 \mathrm{~h}$ during $9 \mathrm{~d}$. Each counting was developed by employing the turbidimetric method to $520 \mathrm{~nm}$ (Kästner et al., 1994), transforming the absorbance readings into $\mathrm{CFU}$ as pointed out by Escalante (2002). The $\mathrm{pH}$ and temperatures values were measured every $24 \mathrm{~h}$ during the time the experiment lasted.

\section{Phase II}

Test of bacterial biomass production in a bioreactor (Kettler jar). A Proteus sp biomass production test was performed in a bioreactor with access to sterile air, sample taking and an air outlet to release pressure from the system (venting). According to the in vitro bioassays developed in the last Phase, $1100 \mathrm{~mL}$ of the nutrient medium adjusted to the microbial growth parameters found as optimal, $\quad \mathrm{N}_{2=\text { Triple17 }} \mathrm{pH}_{1=4.0} \mathrm{~T}_{1=29^{\circ} \mathrm{C}}, \quad$ was prepared in a $2000 \mathrm{~mL}$ bioreactor. The culture medium contained in the bioreactor was sterilized during $20 \mathrm{~min}$ at $121^{\circ} \mathrm{C}$ and $103.421 \mathrm{kPa}\left(15 \mathrm{lb}_{\mathrm{f}} \mathrm{plg}^{-2}\right)$. In a aseptic medium, the nutrient medium was inoculated with $9.7 \mathrm{~mL}$ of inoculating medium, prepared in the same way to the one employed in the inoculation for the development of Phase I at this same stage. Afterwards, it was shaken to homogenize and sampled. The initial counting $(\mathrm{t}=0 \mathrm{~h})$, as well as the Proteus sp development evaluation, were performed in the same way as in the former Phase, during $8 \mathrm{~d}$. The temperature and the $\mathrm{pH}$ values were also determined during each bacterial growth evaluation.

\section{RESULTS}

The studied soil, affected by Istmo crude oil (hydrocarbon chain higher than C18), with API index = 33.74 (PEMEX, 1988), presented $3.45 \times 10^{5} \mathrm{mg} \mathrm{kg}{ }^{-1} \mathrm{TPH}$ $(345,000 \mathrm{ppm})$. In Phase I, Stage I, three bacterial strains were obtained. They were named B1, B2 and B3. The counting of bacterial strains found in the soil gave the following values: $24 \mathrm{CFU} \mathrm{g}^{-1}$ soil of $\mathrm{B} 1$, $7 \mathrm{CFU} \mathrm{g}^{-1}$ soil of $\mathrm{B} 2$ and $5 \mathrm{CFU} \mathrm{g}^{-1}$ soil of B3. The bacterial colonies obtained at this phase had diverse morphologies: punctiform, circular and rhizoid, with complete circular filamentous border; with a yellow whitish color, a yellow whitish color circumscribed to the colony, and whitish, respectively (Ramirez, 2001). The three colonies passed to Phase II. From the three strains isolated in Phase I, only the bacterial strain B1 survived in Phase II when in contact with crude oil (Figure 1), and passed to Phase III.

The bacterial strain selected from phase II, named B1, was inoculated in liquid culture medium of combined carbon modified for degrading bacteria of total petroleum hydrocarbon (MLC), with oil as carbon source, where it reached a population of $8.7 \times 10^{9} \mathrm{CFU} \mathrm{mL}^{-1}$ at day 6 (Figure 2). The total removal of the 


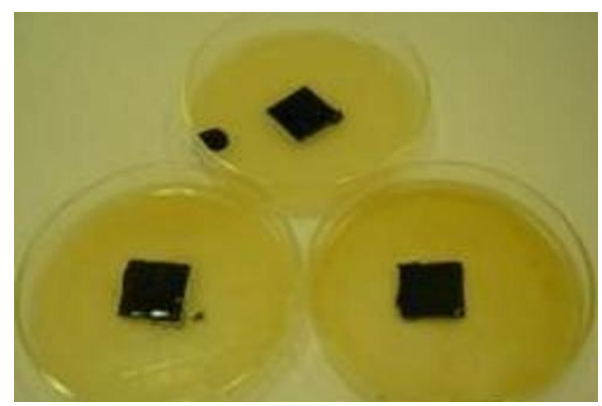

Figure 1. Reproduction of Bacterium B1 (Proteus sp.) on a solid medium.

hydrocarbon layer that was on the MLC surface was observed, forming a stable emulsion. Once the strain B1 was wholly identified as hydrocarbonoclastic, it was classified. The bacterial strain B1was inoculated in Trypticase Soy Agar, Blood Agar and Eosine Methylene
Blue Agar, and from this last culture medium biochemical tests were performed. Microscopic morphological test showed: Bacillus Gram (-); Tests/reaction: catalase $24 \mathrm{~h} /(+)$, oxidase $/(-), \quad \mathrm{H}_{2} \mathrm{~S} /(+) \quad$ production, motility $/(+), \quad$ growth in $\mathrm{KCN} /(+)$; carbohydrates fermentation tests/reaction: Glucose (gas) $/(+)$, Glucose (acid) $/(+)$, Lactose (acid)/(-), Sucrose (acid)/(+), glycerol (acid)/(Variable), maltose/(+), sucrose $/(+)$; IMVIC reaction tests: Indole $/(+)$, methyl $\mathrm{red} /(+), \quad$ VogesProskauer/(-), citrate (Simmons)/(-); Other reactions: nitrate reduction $/(+)$, Lipase $/(+), \quad$ Urease $/(+), \quad$ Catalase $(24$ $\mathrm{h}) /(+)$, use of acetate $/(-)$ and the reaction of Ortho-Nitrophenyl Galactopyranoside/(-). The tests supported the classification of bacterium B1 as Proteus sp.

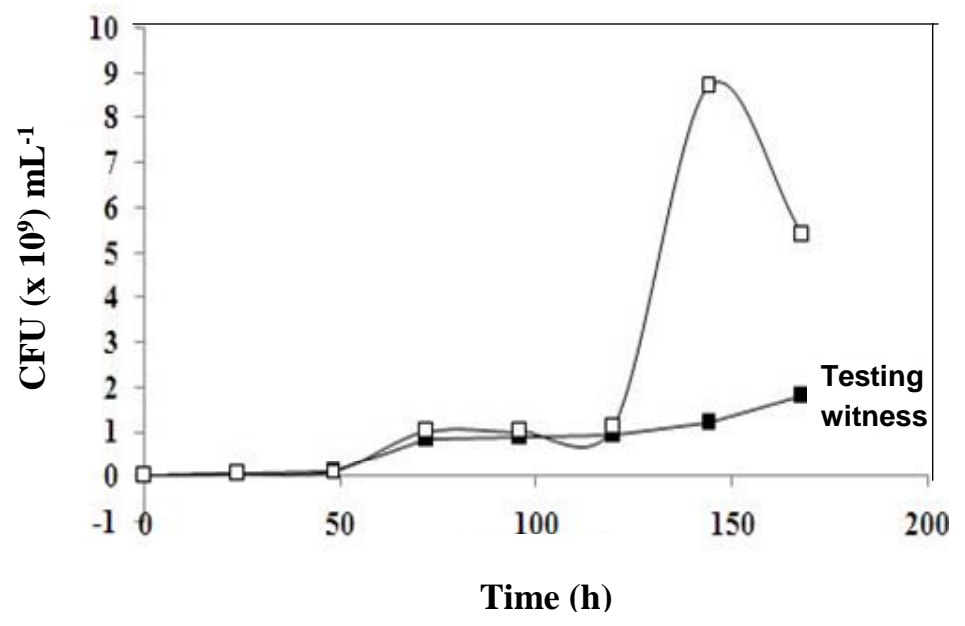

Figure 2. Growth of Colony Forming Units (CFU) of Proteus sp. in liquid mineral medium $(3.5 \times 106 \mathrm{CFU} \mathrm{mL}-1$, to $\mathrm{T}=0 \mathrm{~h})$.

To test Proteus sp growth at a flask level (Phase 1 in Stage II), the bacterial bioassay showed a biomass growth, as evidenced by the gradual turbidity of the immersed culture media. Figure 3 shows the results obtained from the treatments where different experimental conditions of temperature, $\mathrm{pH}$ and nutrients where applied to Proteus sp. It was observed that the microorganisms are better developed 
at a $29^{\circ} \mathrm{C}$ temperature, being less favorable at $35^{\circ} \mathrm{C}$ (Figure 3a). Also, the Proteus sp strains had a higher reproduction in the medium with pure salts, and similarly in the medium prepared with Triple 17 and with Nitrophoska blue, although in either case a smaller development of bacterial population was observed in relation to the nutrient prepared with pure salts. The lowest reproduction was obtained when urea was employed as a nutrient (Figure $3 \mathrm{~b})$. The bacterial strains showed their highest development in $\mathrm{pH} 4.0$, decreasing its development as this variable was increased (Figure 3c).
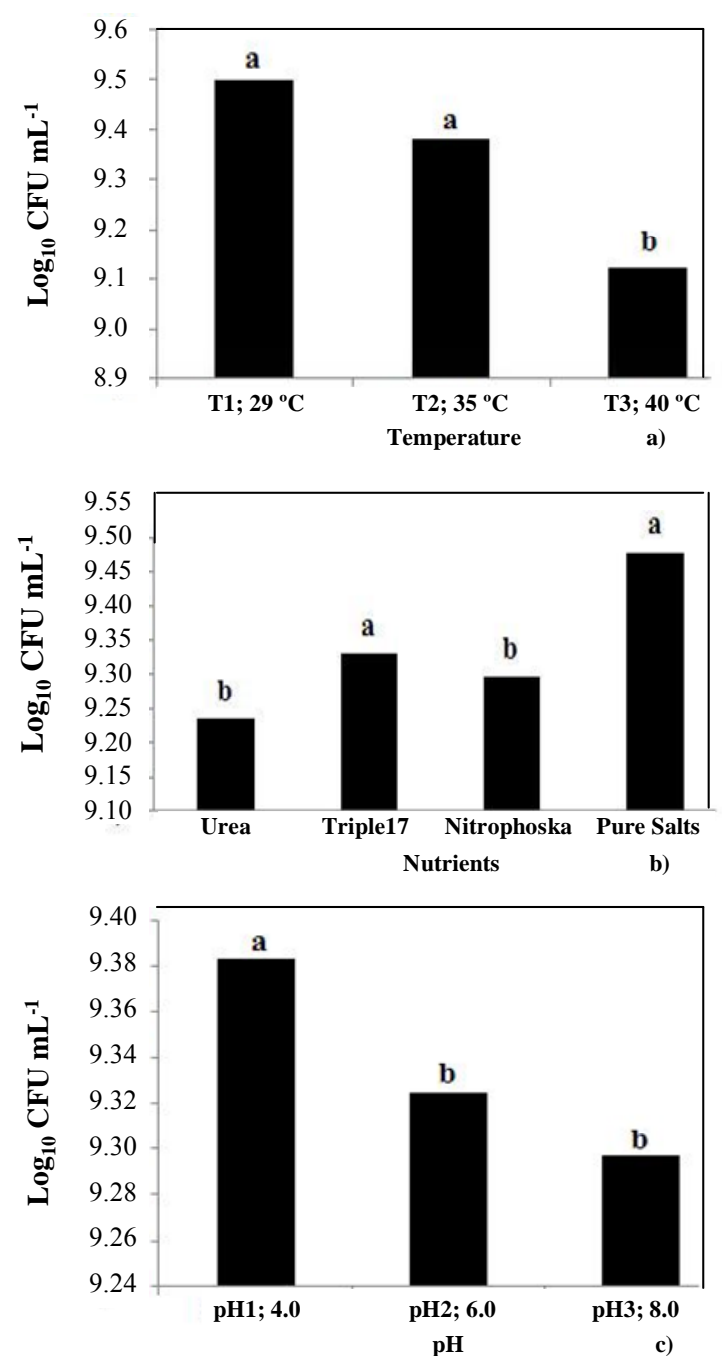

Figure 3. Growth of Proteus sp at different conditions of: a) Temperature, b) Nutrients and c) $\mathrm{pH}$. Treatment means with different letters are statistically significant differences $(\alpha \leq 0.05)$. 
Figure 4 shows the results from the treatments that presented the higher population growth of Proteus sp. The best result was observed to be obtained with the medium $\mathrm{N}_{4=\text { Pure salts }} \mathrm{pH}_{1=4.0} \mathrm{~T}_{1=29^{\circ} \mathrm{C}}$ $\left(\mathrm{N}_{4} \mathrm{pH}_{1} \mathrm{~T}_{1}\right)$, with $1.1 \times 10^{10} \mathrm{CFU} \mathrm{mL}^{-1}$ as the highest population growth at day 9 . However, the bacteria modified the $\mathrm{pH}$ at 8.0. The second significant result was obtained, again, with the Pure salts $\mathrm{N}_{4=\text { Pure }}$ salts $\mathrm{pH}_{1=4.0} \mathrm{~T}_{2=35^{\circ} \mathrm{C}} \quad\left(\mathrm{N}_{4} \mathrm{pH}_{1} \mathrm{~T}_{2}\right)$, while the third best achievement and also the best among the organic nutrient medium was the $\mathrm{N}_{2=\text { Triple17 }} \mathrm{pH}_{1=4.0} \mathrm{~T}_{1=29^{\circ} \mathrm{C}}\left(\mathrm{N}_{2} \mathrm{pH}_{1} \mathrm{~T}_{1}\right)$ with $9.5 \times 10^{9} \mathrm{CFU} \mathrm{mL}^{-1}$ as the highest bacterial growth at day 3 , and a $\mathrm{pH}$ modification of 8.0. There was not a significant difference in the Proteus sp development in the media $\quad \mathrm{N}_{3=\text { Nitrofaskablue }} \mathrm{pH}_{1=4.0} \mathrm{~T}_{1=29^{\circ} \mathrm{C}}$ $\left(\mathrm{N}_{3} \mathrm{pH}_{1} \mathrm{~T}_{1}\right)$ and $\mathrm{N}_{3 \text { Nitrofaskablue }} \mathrm{pH}_{3=8.0} \mathrm{~T}_{1=29^{\circ} \mathrm{C}}$ $\left(\mathrm{N}_{3} \mathrm{pH}_{3} \mathrm{~T}_{1}\right)$, nor between these ones and the medium $\mathrm{N}_{2} \mathrm{pH}_{1} \mathrm{~T}_{1}$, being slightly higher in this last one in relation to the other two nutrient media.

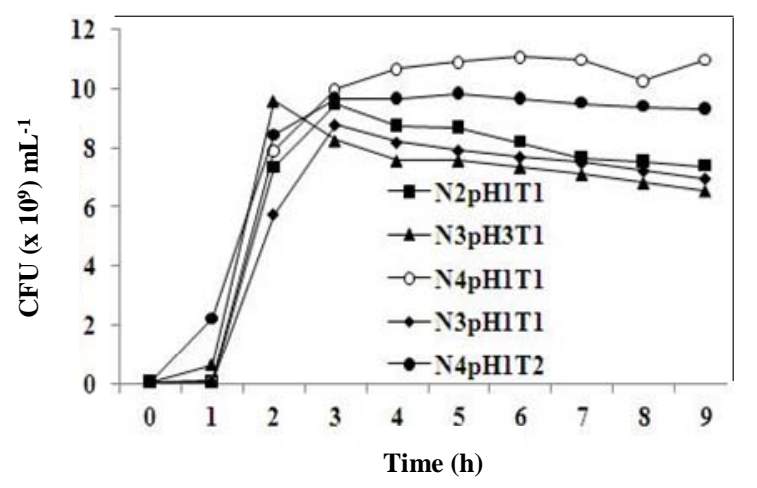

Figure 4. Growth of Proteus sp. on flask treatments $\left(6.8 \times 10^{7} \mathrm{CFU} \mathrm{mL}^{-1}\right.$, to $\left.\mathrm{T}=0 \mathrm{~d}\right)$.

Figure 5 shows the highest population growth obtained from Proteus $\mathrm{sp}$ according to every type of nutrient medium of inoculation. It was clearly observed that the medium with the smallest bacterial development was the one prepared with Urea.

To count the Proteus sp growth in the bioreactor (Phase II, stage II) it was taken into account that the optimal experimental treatment was the one that used $\mathrm{N}_{4} \mathrm{pH}_{1} \mathrm{~T}_{1}$ as the nutrient medium, whereas $\mathrm{N}_{2} \mathrm{pH}_{1} \mathrm{~T}_{1}$ was the most suitable organic medium. In either case, the $\mathrm{pH}$ was modified to 8.0 at the end of the process. The evaluation of the bacterial strain population dynamics in the bioreactor was carried out with the medium $\mathrm{N}_{2} \mathrm{pH}_{1} \mathrm{~T}_{1}$ because, apart from being the most favorable of the organic nutrient media, it was also the most cost-effective among all the media evaluated in the experiment design, making it possible to be applied in larger scales. Thus, in the medium $\mathrm{N}_{2} \mathrm{pH}_{1} \mathrm{~T}_{1}$, the exponential phase is observed in the first four days of the sowing, reaching $4.6 \times 10^{10} \mathrm{CFU} \mathrm{mL}^{-1}$ as its highest development at day 4, then decreases cell number so not as pronounced (Figure 6). 


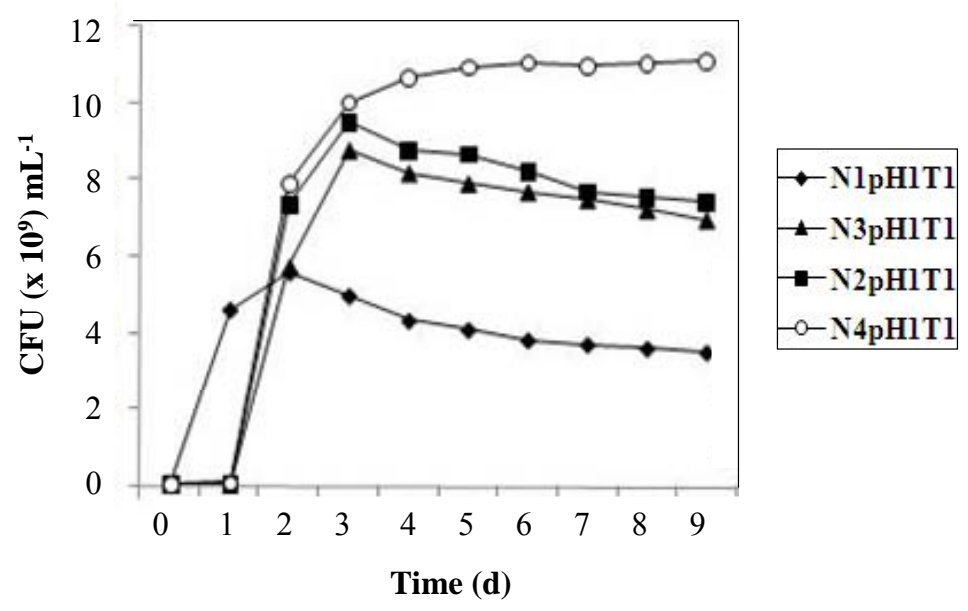

Figure 5. Better development of Proteus sp. for each type of treatment to the flask. $(6.8 \mathrm{x}$ $10^{7} \mathrm{CFU} \mathrm{mL} \mathrm{m}^{-1}$, to $\left.\mathrm{T}=0 \mathrm{~d}\right)$.

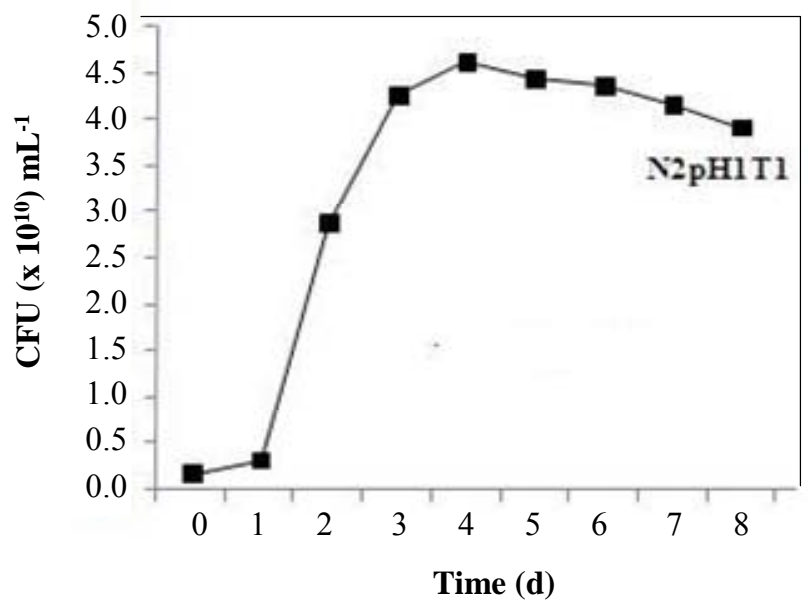

Figure 6. Growth of Proteus sp. on bioreactor treatment $\left(4.3 \times 10^{8} \mathrm{CFU} \mathrm{mL} \mathrm{m}^{-1}\right.$, to $\left.\mathrm{T}=0 \mathrm{~d}\right)$.

\section{DISCUSSION}

From the bacterial populations found in the studied soil, with $3.45 \times 10^{5} \mathrm{mg} \mathrm{kg}^{-1}$ TPH $(345,000 \mathrm{ppm})$ of Istmo crude intemperized oil, the strain B1 had the highest population growth with $24 \mathrm{CFU}$ $\mathrm{g}^{-1}$ soil in relation to B2 and B3 (7 and 5 CFU $\mathrm{g}^{-1}$ soil, respectively). The reason, according to Atlas et al. (1991) and Ercoli 
et al. (2000) is the existence of microbial populations deteriorated by the pollution of the soil. As a result, there is a decrease in the population caused by the environmental stress (in this case, the hydrocarbons), despite their total adaptation to this soil (20 years of pollution), since they have had enough time to change their metabolism and utilize crude oil as a carbon source (Figure 1). Besides, TPH-tolerant bacteria obtained from oil polluted soils can be considered, according to Rivera-Cruz (2002), as specialized and oil degrading strains because they have the capability to be reproduced in soils with high oil concentrations.

Similar results were found by Rosemberg and Ron (1998), with Gramnegative pure strains. Pure bacteria survival at this selection phase, in laboratory conditions, suggests that they have the capacity to use aliphatic and aromatic hydrocarbons as electron donors. All organisms need carbon to grow. In fact, a typical cell contains $50 \%$ of carbon (Madigan et al., 2003). Subsequently, microbial growth of strain B1 was tested in a liquid culture medium of combined carbon modified for degrading bacteria of total petroleum hydrocarbon (MLC), having as the only carbon source the Istmo Crude oil, and finding a population development of $8.7 \times 10^{9} \mathrm{CFU} \mathrm{mL}^{-1}$ at day 3 (Figure 2). In this medium, a stable emulsion was observed with the total removal of the superficial hydrocarbon layer. This could be due to the production of biosurfactants produced by strain itself, that contribute to solubilize the hydrocarbons and in this way the microorganism can be able to degrade the hydrocarbon chain, using its metabolism (Girard, 1998; Leahy and Colwell, 1990; Rosemberg and Ron, 1998; Parales and Harwood, 2002; Johnsen and Karlson, 2007). After that, the bacterial population
B1 was evaluated at a gender level. Biochemical tests were performed and their results gave enough evidence to classify it as Proteus sp. In the current literature, there have not been reported studies about Proteus sp as a single strain useful to degrade oil-derived hydrocarbons in soils. There is a scarce and limited reference to its participation in other experimental conditions where it was part of microbial consortiums in bioremediation of effluents polluted by oil from a fertilizing plant (Adoky and Orugbani, 2007), but nothing is found concerning soils affected by oil spills.

Proteus sp. population showed significant statistical differences in the means (Tukey $\alpha \leq 0.5$ ), with $9.5 \times 10^{10}$ $\mathrm{CFU} \mathrm{mL}^{-1}$ (Figure $3 \mathrm{a}$ ), being $29^{\circ} \mathrm{C}$, the optimal growth temperature. This optimal growth parameter can be attributed, according to Szabo and Paterson (2002), to the fact that Proteus sp activity reaches its maximum potential at temperatures around $30^{\circ} \mathrm{C}$. At this temperature, the enzymatic reactions are faster and the cell division increases. Likewise, Alexander (1994) claims that bacteria have their optimal growth at a temperature range that goes from $28^{\circ} \mathrm{C}$ to $39^{\circ} \mathrm{C}$. From the population tested with the nutrient-related treatments, significant statistical evidence was reported (Tukey $\alpha \leq 0.5$ ) (Figure 3b), having the higher population $9.74 \times 10^{10}$ $\mathrm{CFU} \mathrm{mL} \mathrm{mL}^{-1}$ in the treatment with Pure salts. A reason could be that it contains nitrogen, phosphorus, potassium, in addition to other micronutrients as iron, copper, zinc, sulfur, cobalt, manganese, magnesium and calcium, etc. These necessary nutrients allow the microorganism to synthesize their main biomolecules, degrade molecules integrated by carbon, hydrogen and oxygen, and obtain energy (Walton et al., 1994; Ercoli et al., 2000; Prescott et al., 2004). Figure 3c shows significant 
statistical differences (Tukey $\alpha \leq 0.5$ ), since it evidenced the highest population growth with $9.38 \times 10^{10} \mathrm{CFU} \mathrm{mL}^{-1}$ in the treatment $\mathrm{pH}_{1=4.0}$, though Proteus $\mathrm{sp}$ modified it the $\mathrm{pH}$ to 8.0 (slightly alkaline). A possible reason could be that Proteus sp microorganisms produce urease to unfold the urea present in the nutrient, and in such a way it obtains ammonium hydroxide, resulting in the medium alkalinization (Ohno et al., 2000; Prescott et al., 2004). Furthermore, Alexander (1994), Benavides-Rodriguez and Hermida-Silva (2008) report that soil bacteria have their optimal growth in the 6.0 to $8.0 \mathrm{pH}$ rank.

The microbial development in figure 4 showed that the best medium for Proteus sp reproduction was the $\mathrm{N}_{4} \mathrm{pH}_{1} \mathrm{~T}_{1}$ while the best organic medium was $\mathrm{N}_{2} \mathrm{pH}_{1} \mathrm{~T}_{1}$, although it did not have significant differences in its results to the ones obtained in $\mathrm{N}_{3} \mathrm{pH}_{1} \mathrm{~T}_{1}$ and $\mathrm{N}_{3} \mathrm{pH}_{3} \mathrm{~T}_{1}$, which had lower maximum values of bacterial growth and plateau of subsequent development. The difference between the highest development obtained in media $\mathrm{N}_{2} \mathrm{pH}_{1} \mathrm{~T}_{1}$ and $\mathrm{N}_{3} \mathrm{pH}_{1} \mathrm{~T}_{1}$ was $7.3 \times 10^{8} \mathrm{CFU}$ $\mathrm{mL}^{-1}$, still being higher the development in the medium $\mathrm{N}_{4} \mathrm{pH}_{1} \mathrm{~T}_{2}$. This indicates close achievements in Proteus sp. population growth between media Triple 17 and Nitrophoska blue in similar temperature conditions and $\mathrm{pH}$. Likewise, Figure 5 shows that the nutrient medium prepared with Urea is the one that had the lowest Proteus sp. reproduction among all tested media in the experimental design. Also, the cost in México (a $50 \mathrm{~kg}$ sack in American dollar) of each nutrient employed in this project was: Urea \$21.34, Triple 17 \$25.77, Nitrophoska blue $\$ 61.04$. For pure Salts: $250 \mathrm{~g}$. $\mathrm{Na}_{2} \mathrm{HPO}_{4}$ bottle $\$ 24.15 ; 250$ g. $\mathrm{KH}_{2} \mathrm{PO}_{4}$ bottle $\$ 28.66 ; 500$ g. $\mathrm{NH}_{4} \mathrm{CI}$ bottle $\$ 48.31 ; 500$ g. $\mathrm{MgSO}_{4} \cdot 7 \mathrm{H}_{2} \mathrm{O}$ bottle $\$ 44.28$.
On the basis of the results shown in Figures 4 and 5, the medium $\mathrm{N}_{2} \mathrm{pH}_{1} \mathrm{~T}_{1}$ was chosen to obtain bacterial biomass in bioreactor, having a nutrient medium (Triple 17), that has higher $\mathrm{N}$ and $\mathrm{P}$ proportions and the same $\mathrm{K}$ proportion than Nitrophoska blue. Besides, apart from giving better bacterial development, it is cheaper than Nitrophoska blue and the medium prepared with pure Salts. Triple 17 was also better than Urea, because Proteus sp. had a higher reproduction in this medium. Triple 17 had also a higher proportion of nutrients NPK and its cost was cheaper than Urea.

A comparison was made between the results obtained in the evaluation of Proteus sp growth in the chosen medium prepared with Triple $17\left(\mathrm{~N}_{2} \mathrm{pH}_{1} \mathrm{~T}_{1}\right)$ in a bioreactor and the one prepared in a flask, (Figures 4 and 6). It was found that, in the flask, the bacterium had an exponential growth in the first three days, with a maximum of $9.5 \times 10^{9} \mathrm{CFU} \mathrm{mL}^{-1}$. Then, it reached a plateau that varied from $8.7 \mathrm{x}$ $10^{9} \mathrm{CFU} \mathrm{mL}^{-1}$ to $7.6 \times 10^{9} \mathrm{CFU} \mathrm{mL}^{-1}$ from day 4 to day 8 . On the other hand, the population development had an exponential growth in the bioreactor, in the first four days, with a maximum of 4.6

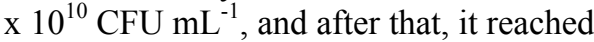
a plateau of growth that varied from $4.4 \mathrm{x}$ $10^{10} \mathrm{CFU} \mathrm{mL}{ }^{-1}$, to $3.9 \times 10^{10} \mathrm{CFU} \mathrm{mL}^{-1}$ from day 5 to day 8 . It was observed that the growth curve is not exactly equal, though it has a similar performance, increasing in a magnitude order, the CFU $\mathrm{mL}^{-1}$ amount in a bioreactor in comparison to the development in the flask. This might be due to the fact that, when the amounts of materials scale up in the bioreactor, there was a better management and control of the medium aeration during the time experiment lasted. In both cases, Proteus sp changed from 4.0 to 8.0 , the medium $\mathrm{pH}$ magnitude. 


\section{CONCLUSION}

The bacterium Proteus sp was isolated and classified in a soil affected by oil spillages contaminated with $3.45 \times 10^{5}$ $\mathrm{mg} \mathrm{kg}^{-1} \quad(345,000 \quad \mathrm{ppm})$ of Total Petroleum Hydrocarbon (TPH). The site is located at the Ejido José Narciso Rovirosa, La Venta, Huimanguillo, Tabasco in Mexico. The strain was adapted to varying conditions of temperature, $\mathrm{pH}$ and four nutrient media. Taking into account the variables in the experimental design as well as the cost of the materials used in the nutrient media, it was found that the treatment with a $29^{\circ} \mathrm{C}$ temperature, $\mathrm{pH} 4.0$ and Triple 17 had the best population growth with $4.6 \times 10^{10}$ $\mathrm{CFU} \mathrm{mL}$. In case of being able to reach this development at polluted soils, by using bioaugmentation and soil conditioning, it could be considered as a bioremediation strategy, with potential to solve the problem of hydrocarbonpolluted soils in Tabasco in particular, and in a nationwide context.

\section{ACKNOWLEDGEMENTS}

This research is part of the POA-2008011 project, "Determining the optimal Parameters to produce fungal and bacterial hydrocarbonoclastic biomass" developed by División Académica de Ingeniería y Arquitectura (DAIA) that belongs to the Universidad Juárez Autónoma de Tabasco (UJAT). It receives partial financing from the company Corporativo de Servicios Ambientales S.A de C.V. (CORSA). The authors want to thank to the Universidad Popular de la Chontalpa (UPCH) for the opportunity to carry out partial lab tests, to DAIA (UJAT), for all the support given in this research, to Ing. Alfredo Castro Betancourt, CORSA S.A de C.V. General Manager, for all the procedures he went through to obtain finance for this research, and to Mr. Luis Farfán Martínez, coordinator of Centro de Apoyo Pedagógico of the Universidad de Atacama, for his support in the organization and conclusion of this document.

\section{REFERENCES}

Adams-Schroeder, R.H., DominguezRodrìguez, V.I., Vinalay-Carrillo, L. 2002. Evaluation of microbial respiration and ecotoxicity in contaminated soils representative of the petroleum producing region of southeastern México. Terra Latinoam. 20, 253265.

Adoki, A., Orugbani, T. 2007. Removal of crude petroleum hydrocarbons by heterotrophic bacteria in soils amended with nitrogenous fertilizer plant effluents. Af. J. of Biotech. 6, 1529-1535.

Alexander, M. 1994. Biodegradation and Bioremediation. Academic Press, San Diego, 302 p.

Arias, S. 2010. Debe Tabasco PIB récord ¡al petróleo!. Tabasco hoy. http://www.tabascohoy.com.mx/noticia.php?id n $\underline{\text { ota }=190648}$

Atlas, M.R., Horowitz, A., Krichevky, M., Bej, K.A. 1991. Response of microbial population to environmental disturbance. Microbial. Ecol. 22, 249-256.

Atlas, R.M., Unterman, R. 1999. Bioremediation. In: A.L. Demain, J.E. Davies (eds.). Manual of Industrial Microbiology and Biotechnology, Second edition. ASM Press, Washington, DC, pp. 666-681.

Baeza, J.R., López, M.L.X., Espinoza de los M., F.J.J., Valerio, A.G., García, G.H.S. 2008. Producción de 1,3-PDO por Lactobacillus reuteri en fermentaciones Batch Glucosa/Glicerol. Memoria del XVI Congreso Nacional de Ingeniería Bioquímica, México, pp: 10-18.

Barathi, S., Vasudevan, N. 2001. Utilization of petroleum hydrocarbons by Pseudomonas fluorescens isolated from a petroleumcontaminated soil. Env. Int. 26, 413-416. 
Benavides-Rodriguez, G.D., Hermida-Silva, A.M. 2008. Aislamiento e identificación de flora bacteriana nativa del suelo de los paramos Cruz verde y Guasca. Tesis de Grado. Pontificia Universidad Javeriana, Bogota Colombia, 118 p.

CIMADES. 1997. Relación de fugas de hidrocarburo localizadas en el campo cinco presidentes periodo de 1989-1987. Gobiernos del estado de Tabasco, Villahermosa, Tabasco. 14 p.

Cruz-Serrano, N. 2009. Amenazan la salud 297 áreas contaminadas. El Universal. http://www.eluniversal.com.mx/nacion/169709.ht $\mathrm{ml}$

Cruz-Serrano, N. 2010. Pemex, tercera petrolera en el mundo en 2009. El Universal http://www.eluniversal.com.mx/finanzas/80420.h $\underline{\mathrm{tml}}$

Davis, J.B. 1997. Petroleum Microbiology. Elsevier, Amsterdam, $604 \mathrm{p}$.

Ercoli, E., Gálvez, J., Di Paola, M., Cantero, J., Videla, S., Medaura, M., Bauzá, J. 2000. Análisis y evaluación de parámetros críticos en biodegradación de hidrocarburos en suelo. En Congreso Producción. III Workshop Latinoamericano sobre aplicaciones de la Ciencia en la Ingeniería de Petróleo. Puerto Iguazú. Argentina. Formato electrónico.

EPA. 1999. Method-1664A. Analytical method guidance for EPA method 1664A implementation and use (40 CFR part 36) http://www.epa.gov/waterscience/methods/metho d/oil/1664guide.pdf

EPA. 1996. Method-3540C. Soxhlet Extrac-tion. http://www.epa.gOv/wastes/hazard/testmethods/s w846/pdfs/3540c.pdf

EPA. 1998. Method-9071B. n-hexane extractable material (hem) for sludge, sediment, and solid samples. http://www.caslab.com/EPAMethods/PDF/EPA-Method-9071B.pdf

Escalante, G.R.M. 2002. Biodegradación de crudo de petróleo en terrarios. Tesis de maestría en biotecnología. Universidad Nacional Mayor de San Marcos, Lima, 51 p.

Eweis, J., Ergas, S., Chag, D., Schoroeder, E. 1999. Principios de Biorrecuperación. McGrawHill, Madrid, 327 p.

Frankenberger, Jr.W.T. 1992. The need for a laboratory feasibility study in bioremediation of petroleum hydrocarbons. In: E.J. Calabrese, P.T
Kostecki (eds.). Hydrocarbon contaminated soils and groundwater. Lewis Pub., Boca Raton, FL, pp. 237-293.

Girard, R.H. 1988. Biodegradación microbiana del petróleo en ecosistemas acuáticos. Gerencia de Coordinación y Control de Protección Ambiental, PEMEX, México, 70 p.

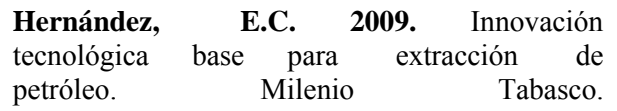
http://impreso.milenio.com/node/8675165

Holt, G.J., Krieg, R.N., Sneath, H.A.P., Staley, T.J., Williams, T.S. 1994. Bergey's manual of determinative bacteriology. Lippincott Williams and Wilkins, Maryland, $787 \mathrm{pp}$.

INEGI. 2001. Síntesis de información geográfica del estado de Tabasco. México D.F. 118 p.

INEGI. 2009. Comunicado Núm. 203/09. 10 p.

Johnsen, A.R., Karlson, U. 2007. Diffuse PAH contamination of surface soils: environmental occurrence, bioavailability, and microbial degradation. Appl. Microbiol. and Biotech. 76, 533-543.

Kästner, M., Breuer-Jammali, M., Mhro, B. 1994. Enumeration and characterization of the soil sites to mineralize polycyclic aromatic hidrocarbons. Appl. Microbiol. Biotechol. 41, 267-273.

Lajous-Vargas, A. 1997. Compromisos de Pemex con la protección del medio ambiente en el estado de Tabasco. Inauguración de la construcción de una nueva planta procesadora de gas natural en el C.P.Q. Ciudad Pemex. Presente, Villahermosa, Tabasco. 14-15 A

Leahy, J.G., Colwell, R.R. 1990. Microbial degradation of hydrocarbons in the environment. Microbiol. Rev. 54:305-315.

Lee, K., Levy, E. M. 1989. Biodegradation of petroleum in the marine enviroment and its enhancement. In: J. O. Nriagu, J. S. S. Lakshminarayana (eds.). Aquatic toxicology and water quality management. John Wiley and Sons, Inc., New York, pp. 217-243.

Levin, M., Gealt, M. 1997. Biotratamiento de Residuos Tóxicos y Peligrosos. McGraw-Hill. Madrid, $354 \mathrm{p}$.

Madigan, M.T., Martinko J.M., Parker, J. 2003. Brock. Biología de los microorganismos. Prentice Hall, Madrid, 1096 p. 
Odum, E., Sarmiento, F. 1998. Ecología: el puente entre ciencia y sociedad. McGraw-Hil Interamericana, México, 343 p.

Ohno, A., Ishii, Y., Ma, L., Yamaguchi, K. 2000. Problems related to determination of MICs of oximino-type expanded-spectrum cephems for Proteus vulgaris. J. Clin. Microbiol. 38, 677-681.

Parales, R., Harwood, C. 2002. Bacterial chemotaxis to pollutants and plant-derived aromatic molecules. Current Opinion in Microbiology 5, 266-273.

Pelczar, Jr. M.J., Reid R.D., Chan, E.C.S. 1998. Microbiología. Mc Graw Hill. México, 826 p.

PEMEX. 1988. El petróleo. Edición revisada y redactada por H. Covantes, Petróleos Mexicanos, México, D.F., 176 p.

Prescott, L., Harley, J.P., Klein, D.A. 2004. Microbiologia. McGraw-Hill Interamericana, Madrid, $1272 \mathrm{p}$.

Ramírez, G. R. 2001. Manual de Prácticas de Microbiología General. Facultad de Química, UNAM., México 257 p.

Ramos-Mora, P. 2010. Pemex: la viga en el ojo del gobierno de México. Suite101.net. http://www.suite101.net/content/pemex-la-vigaen-el-ojo-del-gobierno-de-mexico-a19972

Rennie, R.J. 1981. A single medium for the isolation of acetylene-reducing (dinitrogenfixing) bacteria for soils. Can. J. Microbiol. 27, 8 14.

Rivera-Cruz, M.C. 2001. Microorganismos rizosféricos de los pastos alemán (Echinochloa polystachya H.B.K. Hitche) y cabezón (Paspahum virgatum L.) en la degradación del petróleo crudo y el benzo(a)pireno. Tesis de doctorado, Colegio de Postgraduados, Montecillo, Texcoco, México, 348 p.

Rivera-Cruz, M.C., Ferrera-Cerrato, R., Volke-Haller, V., Rodríguez-Vázquez R., Fernández-Linares, L. 2002. Adaptación y selección de microorganismos autóctonos en medios de cultivos enriquecidos con petróleo crudo. Terra Latinoamer. 20, 423-434.
Rosenberg, E., Ron, E.Z. 1998. Bioremediation of petroleum contamination. In: R. L. Crawford, D. L. Crawford (eds.). Bioremediation: Principles and applications. Cambridge University Press., Cambridge, UK., pp: 100-124.

Secretaría de Medio Ambiente y Recursos Naturales.2000. Evaluación de la conformidad para muestreo de suelos. Norma Oficial Mexicana NOM-021-RECNAT. Diario Oficial de la Federación. Segunda Sección, Apartado 6.1. Diciembre de 2002

Seklemova, E., Pavlova, A., Kovacheva, K. 2001. Biostimulation based bioremediation of diesel fuel: Field demonstration. Biodegrad. 12, 311-316.

Sugiura, K., Ishihara, M., Shimauchi, T., Harayama, S. 1997. Physicochemical Properties and Biodegradability of Crude Oil. Environ. Sci. Technol. 31, 45-51.

Szabo, D., Paterson, D. 2002. Proteus species. In: V. L. Yu, R. Weber, D. Raoult (eds). Antimicrobial therapy and vaccines Volume I: Microbes. Apple Tree Productions, Maryland, pp: 537-544.

Walter, M.V. 1997. Bioaugmentation. In: C. J. Hurst (ed). Manual of Environmental Microbiology. ASM Press, Washington, DC, pp. 753-765.

Walton, B.T., Guthrie, E.A., Hoylman, A.M. 1994. Toxicant degradation in the rhizosphere. In: T. A. Anderson, J. R. Coats (eds). Bioremediation through rhizosphere technology Volumen 563. American Chemical Society, Washington, DC, pp. 11-26.

Watanabe, K. 2001. Microorganisms relevant to bioremediation. Curr. Opin. Biotech. 12, 237 241.

Zavala-Cruz, J., Gutiérrez, C., Palma-López, D.J. 2003. Impacto ambiental en las tierras del campo petrolero, Samaria, Tabasco. Colegio de Postgraduados, CONACYT, CCYTET. Villahermosa, Tabasco, $131 \mathrm{p}$. 